Hydrol. Earth Syst. Sci., 17, 2323-2337, 2013

www.hydrol-earth-syst-sci.net/17/2323/2013/

doi:10.5194/hess-17-2323-2013

(C) Author(s) 2013. CC Attribution 3.0 License.

\title{
Modeling post-fire water erosion mitigation strategies
}

\author{
M. C. Rulli ${ }^{1}$, L. Offeddu ${ }^{1}$, and M. Santini ${ }^{2}$ \\ ${ }^{1}$ Politecnico di Milano, Piazza L. Da Vinci, 32, Milano, 20133 Italy \\ ${ }^{2}$ Centro euroMediterraneo sui Cambiamenti Climatici, Lecce, Italy \\ Correspondence to: M. C. Rulli (cristina.rulli@ polimi.it)
}

Received: 4 September 2012 - Published in Hydrol. Earth Syst. Sci. Discuss.: 27 September 2012

Revised: 30 April 2013 - Accepted: 21 May 2013 - Published: 27 June 2013

\begin{abstract}
Severe wildfires are often followed by significant increase in runoff and erosion, due to vegetation damage and changes in physical and chemical soil properties. Peak flows and sediment yields can increase up to two orders of magnitude, becoming dangerous for human lives and the ecosystem, especially in the wildland-urban interface. Watershed post-fire rehabilitation measures are usually used to mitigate the effects of fire on runoff and erosion, by protecting soil from splash and shear stress detachment and enhancing its infiltration capacity. Modeling post-fire erosion and erosion mitigation strategies can be useful in selecting the effectiveness of a rehabilitation method. In this paper a distributed model based on the Revised Universal Soil Loss Equation (RUSLE), properly parameterized for a Mediterranean basin located in Sardinia, is used to determine soil losses for six different scenarios describing both natural and post-fire basin condition, the last also accounting for the single and combined effect of different erosion mitigation measures. Fire effect on vegetation and soil properties have been mimed by changing soil drainage capacity and organic matter content, and RUSLE factors related to soil cover and protection measures.

Model results, validated using measured data on erosion rates from the literature and in situ field campaigns, show the effect of the analyzed rehabilitation treatments in reducing the amount of soil losses with the peculiar characteristics of the spatial distribution of such changes. In particular, the mulching treatment substantially decreases erosion both in its mean value $(-75 \%)$ and in the spatially distribution of the erosion levels over the burned area. On the contrary, the breaking up of the hydrophobic layer decreases postfire mean soil losses of about the $14 \%$, although it strongly influences the spatial distribution of the erosion levels.
\end{abstract}

\section{Introduction}

Forest fires in the Mediterranean area are natural processes due to the mutual interactions between climate and vegetation, forging the biodiversity typical of this ecosystem (e.g. Ursino and Rulli, 2011; Pausas and Paula, 2012). During the last decades the number, extent and severity of forest fires in the Mediterranean countries increased as a result of abandonment of agricultural lands, inadequate forest management, long seasonal droughts, environmental disturbances, and human activities (e.g. Soulis et al., 2010; Rulli et al., 2006; Rosso et al., 2007; Shakesby, 2011), leading to the alteration of the natural fire regime. Consequently, areas usually experiencing frequent low-severity fires are now hit by less frequent high-severity fires, and other areas (adapted to high-severity fire) are now subjected to an increase in fire frequency (Fulé et al., 2008). As a result, the Mediterranean ecosystem is reducing its resilience to fire. Appropriate mitigation strategies can reduce the negative consequences of fire through a deep comprehension of fire effects and sustainable coexistence with forest fires, in terms of both human security and ecological processes (Pausas and Verdù, 2008).

Fire effects consist of direct damage of vegetation and alteration of physical and chemical soil properties, which in turn affect hydrological response and sediment erosion and transport (e.g. Moody et al., 2008; Andreu et al., 2001). In particular, both runoff and even more erosion in the first year after fire occurrence often increase by several times compared to natural conditions (Rulli and Rosso, 2005). Measurements taken in the Sila Massif in Calabria (Italy) showed an $87 \%$ increase in runoff on areas recently burned compared to non-burned areas (Terranova et al., 2009), and rainfall simulations in Liguria (Italy) showed post-fire overland flow and sediment yield, respectively, one and two orders of 
magnitude higher in a recently burnt site than in a long term unburned site (Rulli et al., 2006).

Although the association among wildfire, flooding, increase in erosion and sedimentation has been observed all over the world (e.g. Benavides-Solorio and Mac Donald, 2005; Cerdà, 1998; Emmerich and Cox, 1994; Moody et al., 2013; Shakesby, 2011; Terranova et al., 2009), post-wildfire research, especially regarding fire-induced erosion enhancement, has a relatively brief history in the Mediterranean, starting from about the early 1980s (corresponding to the dramatic increase in fire activity) (Shakesby, 2011).

Burn severity has been identified as one of the most important variables affecting post-fire changes in runoff response and soil losses (e.g. Fox et al., 2008). From low to high burn severity, the effect on erosion may vary from more than two orders of magnitude to only sevenfold, or no difference at all (Shakesby, 2011). Besides burn severity, many other factors concur in controlling post-fire runoff and erosion. Among these are loss of organic matter (e.g. Soto and Diaz-Ferros, 1998), increase of bulk density (Neary et al., 2005), reduction of soil porosity and infiltration capacity (Robichaud et al., 2010), and increase of soil water repellency (e.g. De Bano, 2000; Doerr et al., 2009). Other important factors are rainfall intensity, slope and aspect, antecedent soil moisture (Wischmeyer and Smith, 1978), soil aggregate stability (Fox et al., 2008), grade of soil water repellency (Keizer et al., 2008), and the time interval between the fire episode and the occurrence of rainfall (Rulli et al., 2006). Univariate analysis conducted on sediment yields in Colorado Front Range burned hillslopes showed that about $77 \%$ of the variability in post-fire erosion rates is explained by five main factors: fire severity, bare soil percent cover, rainfall erosivity, soil water repellency and texture. Among these, bare soil percentage and rainfall erosivity alone explained $66 \%$ of variability in soil loss measurements (Benavides-Solorio and Mac Donald, 2005).

Strategies for watershed post-fire rehabilitation are mainly aimed to restore soil cover and infiltration capacity and to reduce sediment detachment and downslope sediment transport (e.g. Fernàndez et al., 2010; Myronidis et al., 2010; Neary et al., 2005; Robichaud et al., 2010; Wohlgemuth et al., 2009), therefore acting mostly on soil characteristics like soil vegetation cover, erodibility, permeability or infiltration capacity.

Most ecosystems are adapted to the fires and recovery is carried out by nature. Cerdà and Doerr (2005) show how the recovery of the Mediterranean lands can take place without any human interference, observing during their $11 \mathrm{yr}$ field campaigns a time of 2-4 yr for the recovery. Moreover, immediately post-fire, the presence of ash, especially when covered with needles, can control and mitigate soil losses and protect the soil from rainfall erosivity (Cerdà and Doerr, 2008). Nevertheless, the rainfall regime, characterized by heavy intensity rainfall occurring right after the fires season in some of the Mediterranean areas (e.g. Liguria, Tuscany, Sicily, etc.), the high spatial and temporal variability of rainfall and its associate hydrogeomorphological response, and the occurrence of the fires at the rural-urban interface require prompt post-fire erosion reduction treatments. There are many different mitigation strategies, suitable for diverse situations and whose results depend on when, how and where they are applied (Wohlgemuth et al., 2009).

Post-fire treatments may be applied to hillslopes, channels and roadways. Treatments used on hillslopes can be divided in three main types: mulch treatments, erosion barriers and chemical treatments (Neary et al., 2005; Robichaud and Elliot, 2006). Hillslope treatments are designed to avoid sediment delivery to downstream water bodies and they are considered to be the most useful (Robichaud et al., 2010). Wagenbrenner et al. (2006) observed ground cover greatly influencing sediment production, meaning that the better performing treatments will be those immediately increasing the amount of ground cover and facilitating vegetative regrowth. Among these, mulch treatment is considered as one of the most effective watershed rehabilitation treatments, consisting in spreading mulch on burned slopes in order to provide soil surface cover prior to vegetation regrowth. It produces soil protection from rain splash detachment and soil stabilization (Robichaud et al., 2007b; Wohlgemuth et al., 2009). For this purpose, several materials can be used, such as dry straw or wood-based mulches, and wet mulches (hydromulch) mixed with water to form a slurry (Neary et al., 2005). Post-fire mulching needs to provide $60-80 \%$ ground cover to reduce hillslope erosion (Robichaud et al., 2010). Some problems can arise by using this technique, resulting in mulched slopes slipping down, aerially spread mulches residual vegetation interception, so reducing the actual ground cover and potential effectiveness (Neary et al., 2005; Robichaud et al., 2010).

Erosion barriers are commonly placed in a way to capture sediments and interrupt long flow paths, thereby decreasing downslope shear stress soil erosion and sediment transport on hillslopes and into streams. Erosion barriers can be contour-felled logs, straw wattles, contour trenches, or straw bales (Neary et al., 2005). A barrier treatment performance can be defined as the ratio of dry weight of sediment stored by the barrier and dry weight of collected sediment below the barrier. Erosion barriers present some weakness-reducing runoff and soil loss for low-intensity rain events, but do not achieve significant results for high-intensity events. In addition, the capacity of barriers can be overtopped soon after the first rain events, determining the uselessness of uncleaned barriers (Robichaud et al., 2010).

Rehabilitation treatments like ploughing or tilling on croplands' burned areas are usually used to decrease soil aggregation and to break up the fire-induced water-repellent soil layer to restore drainage capacity (Keizer et al., 2008).

Channel rehabilitation after fire is primarily done by cleaning channel beds and preventing obstruction of streams due to the woody debris produced by the fire (Bocchiola et al., 2008). The main treatments for these purposes are check dams or debris basins, debris clearing and streambank 
armoring (Neary et al., 2005). Even if fire does not directly affect the road drainage system, the increased overland flow can overwhelm its capacity. Mitigation measures as waterbars and bypasses, culvert improvements, ditch cleaning and armoring can enhance road drainage system functionality.

Despite the observation of large post-fire increase in soil losses in the Mediterranean area (e.g. Shakesby, 2011 and the references herein), analysis of the efficiency of post-fire erosion mitigation strategies are very scarce. Field studies assessing the effectiveness of mulching and barriers were carried out in Spain (e.g. Badia and Martì, 2000; Bautista et al., 2009; Fernàndez et al., 2011) and in Portugal (Ferreira et al., 2009), but a systematic analysis at basin scale for the Mediterranean area is still lacking.

Given the complexity of fire-related issues, and the importance of fire effects on watershed response and erosion dynamics, accurate predictions of post-fire runoff and sediment yields are needed to guide management decisions, mitigate post-fire soil loss and land degradation and for postfire rehabilitation planning (Fernàndez et al., 2010). Analyses of land use change impacts on soil loss prediction have been carried out by using different kinds of modeling, depending on study area extent, data availability and output degree of accuracy required. The Water Erosion Prediction Project (WEPP) model (Flanagan and Nearing, 1995) and the disturbed-WEPP (Elliot et al., 2001) are process-based erosion prediction models evaluating mean erosion rate in natural and disturbed condition. ERMiT (Robichaud et al., 2007a) is a probability-based erosion prediction model using multiple runs of the WEPP model and developed to predict surface erosion from post-fire hillslopes, and to evaluate the potential effectiveness of various erosion mitigation practices. Empirical models based on the Revised Universal Soil Loss Equation (RUSLE) were used by several authors (e.g. Terranova et al., 2009; Fernández et al., 2010; Ranzi et al., 2012) to account for forest fire and land use change effects on erosion in large-scale basins. A fully distributed hydro-geomorphological model was developed by Rulli and Rosso $(2005,2007)$ for analyzing both the hydrological and erosion and deposition process dynamics for both natural and disturbed basin condition, focusing in particular on post-fire erosion processes in Mediterranean ecosystems.

This paper investigates first-year post-fire erosion mitigation strategies' effectiveness through a distributed model based on the Revised Universal Soil Loss Equation, properly parameterized and validated by using field measurements and literature data, for a Mediterranean basin located in Sardinia, Italy. Soil losses corresponding to six different scenarios are analyzed through appropriate RUSLE parameters changes, thus describing the particular soil treatment to which the study area is subjected. The amount and spatial distribution of soil losses under natural conditions, burned, after tilling/ploughing treatment, after mulching treatment, with barriers and after a combination of the all treatments are examined in detail.

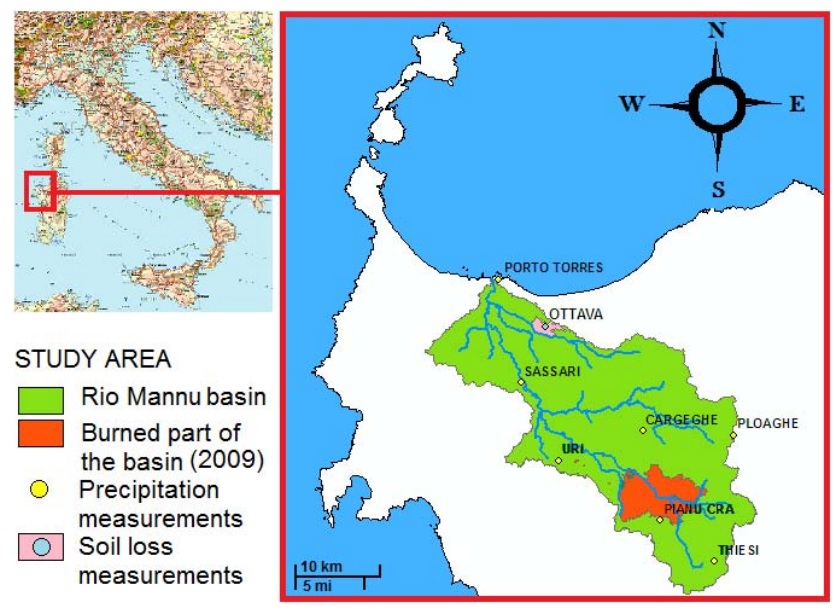

Fig. 1. Rio Mannu watershed, northern Sardinia. The red color represents the burned area following 2009 fire event. The pink area represents field campaigns sites (Porqueddu and Roggero, 1994; Porqueddu et al., 2001). Yellow circles denote rain gauge positions.

\section{Materials and methods}

\subsection{Study area}

The study area is the Rio Mannu River basin, located in northern Sardinia, Italy (Fig. 1).

The basin area is about $650 \mathrm{~km}^{2}$, with a mean elevation of $252 \mathrm{~m}$ a.s.l. (minimum and maximum elevation respectively 0 and $755 \mathrm{~m}$ a.s.1.), and a mean slope of $8.5^{\circ}$ (minimum and maximum slope respectively 0 and $63^{\circ}$ ). Rio Mannu is located in the so-called Fossa Sarda, an area caracterized in the past by marine transgressions, regressions and volcanic activity, when the territory was invaded by the sea and covered with thick sediment layers, forming a big tableland. The geology consists of limestone, granites, volcanic substrates and carbonate deposits. The climate is typically Mediterranean, with hot and dry summers and mild and rainy winters. Precipitation occurs mostly in November and December. Sudden floods may happen in winter, while the summer is usually droughty.

Crops cover $60 \%$ of the basin area with main cultivation represented by olive groves and vineyards, which are $77 \%$ and $10 \%$ of total area, respectively, while $10 \%$ are cork tree plantations (Regione Autonoma della Sardegna, 2006). Shrub and herbaceous vegetation cover $28.4 \%$ of the basin, with $11 \%$ natural pasture, and $10 \%$ typical Mediterranean sclerophyllous vegetation. The urban area is about $4.4 \%$, with Sassari and Porto Torres representing the main urban sites.

Sardinia region is one of the most fire-prone areas in the Mediterranean Basin, experiencing on average 850 fires per year, burning about 19000 ha. During the year 2009, 684 fires occurred on the island, burning $37104 \mathrm{ha}$, most of them $(17000 \mathrm{ha})$ in the same province of the study area; in the 
Table 1. Measured soil loss in Ottava at Rio Mannu Basin.

\begin{tabular}{|c|c|c|c|c|c|c|}
\hline \multirow{3}{*}{$\begin{array}{l}\text { Field } \\
\text { campaigns }\end{array}$} & \multirow{3}{*}{$\begin{array}{l}\text { Mean yearly } \\
\text { precipitation } \\
(\mathrm{mm})\end{array}$} & \multicolumn{5}{|c|}{ Measured soil loss $\left(\mathrm{tha}^{-1} \mathrm{yr}^{-1}\right)$ in Ottava } \\
\hline & & \multicolumn{5}{|c|}{ Soil use } \\
\hline & & $\begin{array}{l}\text { Overall } \\
\text { pasture }\end{array}$ & $\begin{array}{l}\text { Burned } \\
\text { pasture }\end{array}$ & Annual & $\begin{array}{l}\text { Forage } \\
\text { crop }\end{array}$ & Ploughed \\
\hline 1989-1990 & 435 & & 0.09 & 0.05 & 0.59 & 1.04 \\
\hline 1990-1991 & 702 & & 0.08 & 0.06 & 2.86 & 8.38 \\
\hline 1991-1992 & 569 & & 0.6 & 0.57 & 3.83 & 5.45 \\
\hline Mean value & 569 & 2.55 & 0.26 & 0.23 & 2.43 & 4.96 \\
\hline $\begin{array}{l}\text { Field } \\
\text { campaigns }\end{array}$ & $\begin{array}{l}\text { Mean yearly } \\
\text { precipitation } \\
(\mathrm{mm})\end{array}$ & Overall & $\begin{array}{l}\text { Natural } \\
\text { pasture }\end{array}$ & $\begin{array}{l}\text { Improved } \\
\text { pasture }\end{array}$ & $\begin{array}{l}\text { Annual } \\
\text { forage crop }\end{array}$ & $\begin{array}{l}\text { Winter } \\
\text { cereal }\end{array}$ \\
\hline 1994-1995 & 566 & & 0.08 & 0.12 & 2.05 & 1.03 \\
\hline 1995-1996 & 546 & & 0.03 & 0.03 & 0.06 & 0.06 \\
\hline 1996-1997 & 429 & & 0.08 & 0.48 & 3.25 & 1.16 \\
\hline Mean value & 514 & 0.86 & 0.06 & 0.21 & 1.78 & 0.75 \\
\hline
\end{tabular}

Rio Mannu Basin itself, about 4700 ha burned, causing both damages to vegetation (crops and forest) and considerable increase in soil loss (Regione Autunoma della Sardegna, 2006, 2009a) (Fig. 1).

\subsection{Soil loss measurements in the study area}

Measured mean erosion in Mediterranean Europe amounts to $1.3 \mathrm{tha}^{-1} \mathrm{yr}^{-1}$ (Cerdan et al., 2010). In Italy a fortyreservoir sediment deposition dataset, acquired by direct sonar sub-bottom profiler measurements or derived from estimates and measurements carried out by the Italian Electricity Power Company during reservoir dredging (Van Rompaey et al., 2005), reports mean erosion of about $2.3 \mathrm{tha}^{-1} \mathrm{yr}^{-1}$. Concerning the Sardinian region, these measurements show mean erosion of about $4.0 \mathrm{tha}^{-1} \mathrm{yr}^{-1}$. Measurements in Mulargia and Flumendosa basins, located south of the island, show a mean erosion of $5.56 \mathrm{tha}^{-1} \mathrm{yr}^{-1}$ (respectively 10.3 and $0.9 \mathrm{tha}^{-1} \mathrm{yr}^{-1}$ ) (Van Rompaey et al., 2003). Lower values are also recorded in Bonassai, Sassari (SS), south-west of the studied area, where mean erosion rates lie around $0.025 \mathrm{tha}^{-1} \mathrm{yr}^{-1}$ (Acutis et al., 1996), and a field study carried out in Pattada (SS) reports a mean soil loss of $0.034 \mathrm{t} \mathrm{ha}^{-1} \mathrm{yr}^{-1}\left(0.049 \mathrm{tha}^{-1} \mathrm{yr}^{-1}\right.$ on ploughed land, $0.048 \mathrm{tha}^{-1} \mathrm{yr}^{-1}$ on grassland, $0.033 \mathrm{tha}^{-1} \mathrm{yr}^{-1}$ on natural pasture, $0.014 \mathrm{tha}^{-1} \mathrm{yr}^{-1}$ on burned pasture, $0.025 \mathrm{t} \mathrm{ha}^{-1} \mathrm{yr}^{-1}$ on slashed bushland) (Rivoira et al., 1989); the authors themselves, though, note that these values have to be considered quite low for Sardinian conditions. Two field campaigns were carried out in Ottava (SS), a field site in the northern part of the Rio Mannu Basin (Porqueddu and Roggero, 1994; Porqueddu et al., 2001). During the first experiment from 1989 to 1991 , soil loss on several soil uses (permanent pasture, annual forage crop, and continuously ploughed soil) were measured. The second experiment took place from 1994 to 1997 , assessing soil loss data for four common crops of Sardinian hilly areas, which are natural pasture, improved pasture, annual forage crop and winter cereal. During these two experimental campaigns, mean soil loss of respectively 2.55 and $0.86 \mathrm{tha}^{-1} \mathrm{yr}^{-1}$ were measured. Table 1 reports soil losses for each soil use and for each experiment.

\subsection{Soil loss modeling in the study area}

Soil loss in the six different scenarios (that is, natural, burned and after application of single and combined mitigation practices) are analyzed by using a spatially distributed model based on the Revised Universal Loss Equation (RUSLE) (Renard et al., 1997; McCool et al., 1995), parameterized for a Sardinian river basin. RUSLE is commonly adopted in erosion analysis for the simplicity of its structure and inputs and it is recognized to be appropriate for studies such as the present one, where different erosion scenarios are analyzed and compared with each other (e.g. Terranova et al., 2009; Ranzi et al., 2012), which despite its application can produce an overprediction of low sediment fluxes, and underprediction of very high erosion rates (e.g. Terranova et al., 2009; Benavides-Solorio and Mac Donald, 2005; Larsen and Mac Donald, 2007).

The Digitial Elevation Model (DEM) of the basin, at $25 \mathrm{~m}$ resolution, is accurately pre-processed since the RUSLE model is sensitive to the geomorphologic attributes (Menduni et al., 2002). Pits and artificial flat areas are corrected applying the PEM4PIT method (Grimaldi et al., 2004, 2007; Petroselli and Alvarez, 2012; Peroselli, 2012) that allows the 
a

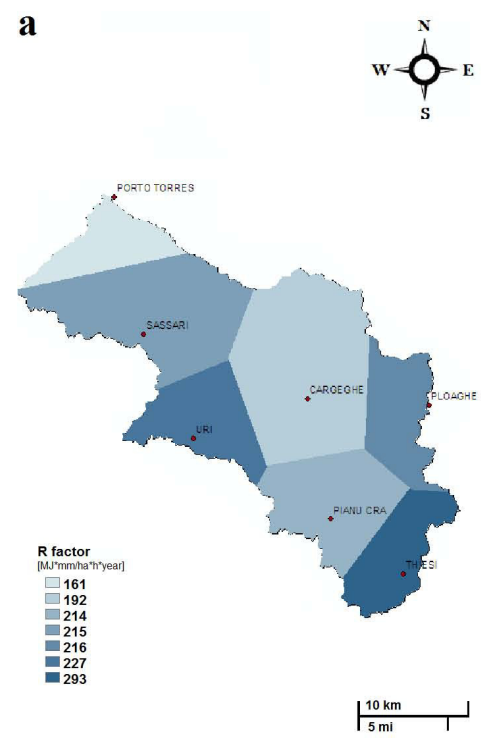

f b

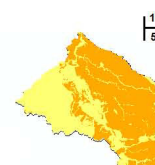

${ }^{10 \mathrm{~km}}, \mathrm{w}_{\mathrm{s}}^{\mathrm{j}} \mathrm{-}$

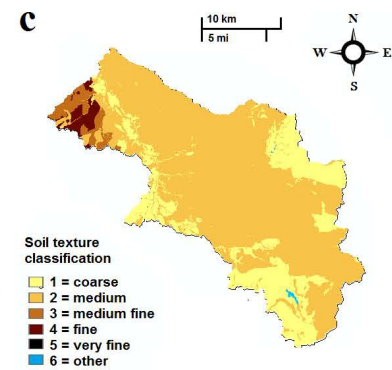

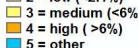
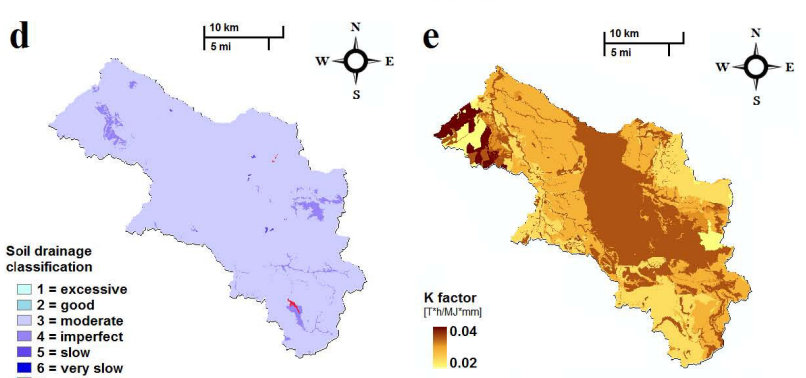

$\begin{aligned} & =\text { imperfect } \\ 5 & =\text { slow } \\ 6 & =\text { very slow } \\ 7 & =\text { other }\end{aligned}$

g
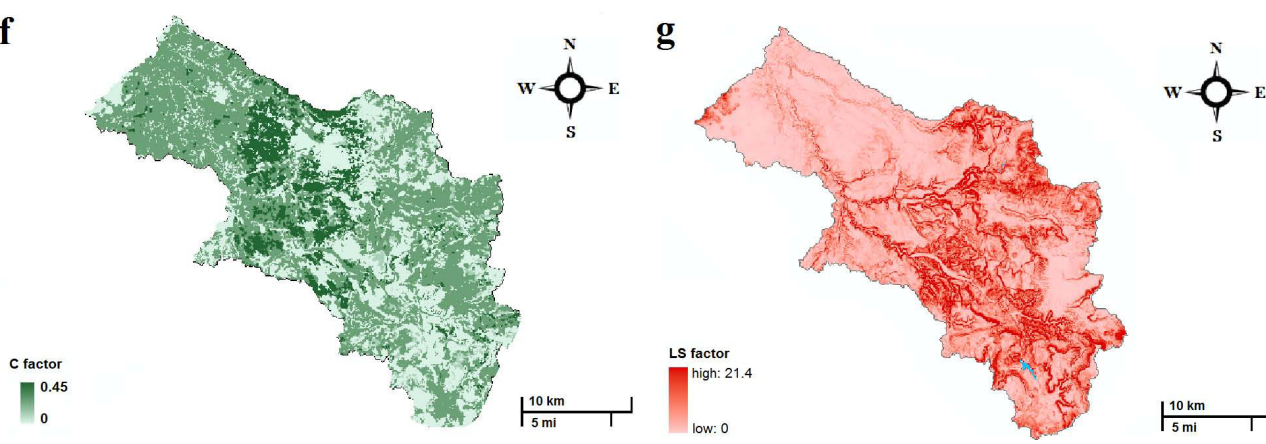

$\mid \frac{10 \mathrm{~km}}{5 \mathrm{mi}}$

Fig. 2. (a) Spatially distributed RUSLE erosivity factor; (b-d) soil organic content classification, soil texture classification, soil drainage classification; (e) RUSLE soil erodibility factor, RUSLE soil cover and management factor; (g) RUSLE slope length and steepness factor.

enforcement of a slope on the erroneous flat cells using a simplified physically based landscape evolution model.

Soil loss is then evaluated for each cell through RUSLE equation. RUSLE quantifies soil losses $\left(\mathrm{tha}^{-1} \mathrm{yr}^{-1}\right)$ as

$A=R K \operatorname{LS} C P$.

\section{$\boldsymbol{R}$ factor}

$R$ is the rainfall-runoff erosivity factor $\left(\mathrm{MJ} \mathrm{mm}^{1-}\right.$ $\mathrm{ha}^{-1} \mathrm{~h}^{-1} \mathrm{yr}^{-1}$ ), calculated on the basis of average monthly cumulated rainfall; the $R$ factor has been determined using the Fournier index, from mean cumulated yearly precipitation $P_{\text {year }}$ and monthly precipitations $P_{i}$.

Given the Fournier index

$F=\frac{\sum_{i=1}^{12} P_{i}^{2}}{P_{\text {year }}}$,

the $R$ factor is calculated as

$R=4.17 F-152$.
In the present study $R$ is obtained for seven rain gauge stations based on monthly rainfall dataset over a period of $15 \mathrm{yr}$ (1982-2007) (Regione Autonoma della Sardegna, 2009b). A spatially distributed $R$ factor has been obtained by applying Thiessen's polygon method.

The $R$ factor ranges from $161 \mathrm{MJ} \mathrm{mm}^{-1} \mathrm{ha}^{-1} \mathrm{~h}^{-1} \mathrm{yr}^{-1}$ in Porto Torres to $293 \mathrm{MJ} \mathrm{mm}^{-1} \mathrm{ha}^{-1} \mathrm{~h}^{-1} \mathrm{yr}^{-1}$ in Thiesi (Fig. 2a).

\section{$K$ factor}

$K$ is the soil erodibility factor ( $\mathrm{th}^{-1} \mathrm{MJ}^{-1} \mathrm{~mm}^{-1}$ ) (Fig. 2e), determined by Renard et al. (1997), and calculated as

$K=\left(k_{0} k_{\mathrm{t}}+k_{\mathrm{s}}+k_{\mathrm{d}}\right) / 759.4$,

where $k_{0}, k_{\mathrm{t}}, k_{\mathrm{s}}$ and $k_{\mathrm{d}}$ are subfactors that depend on different soil characteristics, such as texture, drainage capacity, structure (soil percentage of silt, sand and clay), and organic matter content (Fig. 2b-d).

$k_{0}=12-\operatorname{col} .7 \quad(\mathrm{co}=$ soil organic carbon class $)$ 
Table 2. Drainage class, fertility class, texture class classification based on a pedological map of Sardinia.

\begin{tabular}{l|c|c|c|c|c|c|c}
\hline \multicolumn{7}{c}{ Drainage } \\
\hline Drainage class & excessive & good & moderate & imperfect & slow & $\begin{array}{c}\text { very } \\
\text { slow }\end{array}$ & other \\
\hline Classification & 1 & 2 & 3 & 4 & 5 & 6 & 7 \\
\hline \multicolumn{7}{|c|}{ Fertility } \\
\hline Fertility class & low & medium & \multicolumn{2}{c}{ high } & \multicolumn{2}{c}{ very high } & other \\
\hline Classification & 1 & 2 & \multicolumn{2}{c}{3} & 4 & 5 \\
\hline \multicolumn{7}{|c|}{ Texture } \\
\hline Texture class & coarse & medium & $\begin{array}{c}\text { medium } \\
\text { fine }\end{array}$ & fine & very fine & other \\
\hline \multicolumn{7}{|c|}{ input values } \\
\hline Texture & 1 & 2 & 3 & 4 & 5 & 6 \\
\hline Clay\% & 0.079 & 0.176 & 0.170 & 0.460 & 0.733 & 0 \\
\hline Silt\% & 0.136 & 0.404 & 0.760 & 0.270 & 0.133 & 0 \\
\hline Sand\% & 0.786 & 0.420 & 0.070 & 0.270 & 0.133 & 0 \\
\hline Structure & 1 & 1 & 1 & 1 & 2 & 0 \\
\hline
\end{tabular}

$k_{\mathrm{d}}=2.5 *(\mathrm{~cd}-3) \quad(\mathrm{cd}=$ soil drainage class $)$

$k_{\mathrm{s}}=(2-\mathrm{cs}) * 3.25 \quad(\mathrm{cs}=$ soil structure class $)$

if $v_{\mathrm{fs}}+\%_{\text {silt }} \leq 68 \quad k_{\mathrm{t}}=\mathrm{ct} \quad(\mathrm{ct}=$ soil texture class $)$

if $v_{\mathrm{fs}}+\%_{\text {silt }}>68 \quad k_{\mathrm{t}}=\mathrm{ct}-0.67$

$\left(\mathrm{ct}-2.1\left(6800\left(1-\%_{\text {clay }}\right)^{1.14}\right) / 10000\right)^{0.82}$

$v_{\mathrm{fs}}=0.74 \%_{\text {sand }}-0.62 \%_{\text {sand }}^{2}$

$v_{\mathrm{fs}}=$ percentage of very fine sand

The pedological map of Sardinia has been used for $K$ factor determination. Table 2 reports soil drainage class, fertility class and texture class classification after a pedological map of Sardinia.

\section{LS factor}

LS is the unitless slope length and steepness factor (Fig. 2g), which is mainly based on the cell's slope and contributing area; the LS factor has been calculated using data from basin DEM. The calibration of model parameters has led to the use of the equation proposed by Moore and Burch (1986), where $A_{\mathrm{S}}$ is the area of plot cell per unit width $(25 \mathrm{~m}) ; 22.13$ is the length of the standard USLE plot having the dimension of [L]; $m$ and $n$ are calibration coefficients; and $\beta$ is the cell slope, computed from the basin DEM:

$\mathrm{LS}=(m+1)\left[\frac{A_{\mathrm{S}}}{22,13}\right]^{m}\left[\frac{\sin (\beta)}{\sin \left(5,143^{\circ}\right)}\right]^{n}$.

\section{$C$ factor}

$C$ is the unitless cover and management factor. In this study $C$ (Fig. 2f) has been determined on the base of CORINE Land Cover 2006 (Table 3), as described by Cebecauer et al. (2004). The $C$ factor has been properly determined for each scenario.

\section{$P$ factor}

$P$ is the support practice factor, accounting for the effect of rehabilitation treatments as well as for other features, like roads, streams or railways, or also changes in soil use hampering natural runoff and erosion paths. The $P$ factor is unitless and ranges from 0 to 1 , depending on the type of erosion soil protection strategy. The $P$ factor has been properly determined in each scenario.

\subsection{Study scenarios}

The influence of soil condition (natural and burned) and three rehabilitation practices and their combination on soil losses have been analyzed, referring to six scenarios which are described in the following:

1. The first scenario assesses soil loss at basin scale in natural (unburned) conditions. In this scenario the conservation practices factor $P$ was set equal to 1 all over the basin, except for paved roads, railways and bare surfaces, where $P$ factor was set to 0 . Due to the lack of information on particular conservation practices for the study basin, the other RUSLE parameters have been evaluated as described in the soil loss modeling section.

2. The second scenario analyzes fire effect on soil losses. During the summer of 2009, a forest fire burned about $47 \mathrm{~km}^{2}$ of the study area, as Fig. 1 reports.

In burned areas, fire effects on soil characteristics have been mimed by changing the $C$ factor, soil drainage capacity, and soil organic matter content. Fire, in fact, soil induces aggregation leading to an increase in bulk density and soil compaction and a decrease of soil cohesiveness (Andreu et al., 2001). Moreover, the combustion of the organic matter can lead to the formation of a soil hydrophobic layer, affecting soil hydrologic properties (De Bano, 2000).

Changing of conservation factor $C$ in burned areas has been suggested by several authors. Terranova et al. (2009) assumed $C$ equal to $0.2,0.05$, or 0.01 , corresponding to high, medium or low burn severity for burned areas in the Calabria region (Italy), which has Mediterranean characteristics like the Rio Mannu Basin. Another hypothesis usually adopted is to set $C$ equal to 1 for areas with a percentage cover lower than $15 \%$. In Slovakia, a study on soil erosion assessment set the $C$ factor in the range of $0.35-0.55$ to areas classified as "burnt areas" in the CORINE Land Cover map (Cebecauer et al., 2004). Larsen et al. (2007) assigned $C$ factor to burned areas having a maximum of 0.33 and a mean of 0.2 .

By considering the ecosystem of the Rio Mannu Basin and the fire severity, the $C$ factor for the burned area was set to 0.2 .

Post-fire organic matter decrease has been simulated by considering burned areas having fertility class one level lower than in natural conditions, and soil water repellency 
Table 3. The $C$ factor after 2006 CORINE Land Cover classification.

\begin{tabular}{llll}
\hline Soil use & $C$ factor & CORINE Land Cover Class & Description \\
\hline High & $0.001-0.01$ & $14 \times, 231,31 \times, 32 \times, 41 \times$ & $\begin{array}{l}\text { Artificial vegetated areas, pastures, forests, scrub and } \\
\text { herbaceous associations, inland wetlands }\end{array}$ \\
\hline Moderate & 0.1 & $241,243,244$ & $\begin{array}{l}\text { Annual crops with permanent crops, agricultural land } \\
\text { with natural vegetation, agro-forestry areas }\end{array}$ \\
\hline Low & $0.165-0.0335$ & $211,212,242$ & Arable land, complex cultivation patterns \\
\hline Very low & $0.350-0.550$ & $22 \times, 333$ & Permanent crops, sparsely vegetated areas \\
\hline Not classified & 0 & $11 \times, 12 \times, 13 \times, 331,332,51 \times$ & Urban, industrial, transport units, sands, rocks, waters \\
\hline
\end{tabular}

$\mathbf{a}$

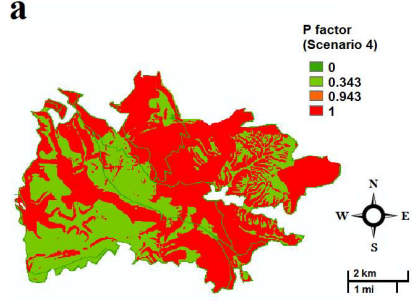

c

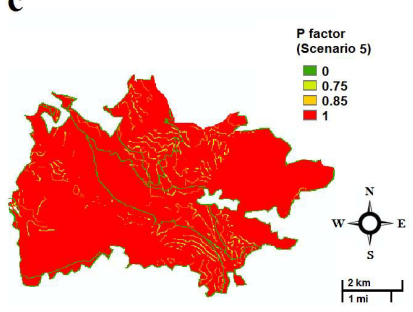

b

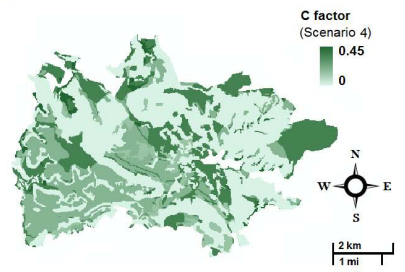

d

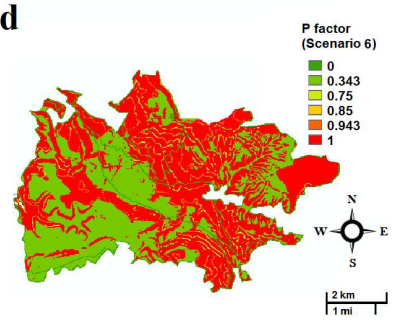

Fig. 3. RUSLE parameters after erosion mitigation strategies.

layer formation has been accounted by reducing soil drainage capacity, which was set to drainage class "very slow".

3. The third scenario analyzes the effects of rehabilitation treatments like ploughing or tilling on crop-burned areas. It mimics the breaking up of the hydrophobic layer by acting on the soil's drainage capacity. The partial restoration of the soil's drainage capacity due to ploughing or tilling has been reproduced by assigning a drainage class to undertreated burned areas one level lower than natural conditions.

4. The fourth scenario studies the mulching rehabilitation practice. Straw mulch is considered one of the more cost-effective stabilization treatments in reducing postfire erosion. Besides, wood mulches provide greater resistance to wind erosion than straw mulch and also they are more decay-resistant than hydromulch (Robichaud et al., 2010).

In this study, both straw and wood mulching on burned forested areas have been considered. In particular, gentle slopes (slope $<30^{\circ}$ ) have been treated with straw mulching

and steeper slopes (30-50\%) with wood chip mulching. The treatment has been applied on about $45 \%$ of the burned slopes. Mulching effect on soil has been mimed by changing RUSLE parameters $P$ and $C$. According to Fernàndez et al. (2010), $P=0.343$ has been used for straw mulching on slopes $<30 \%$ and $P=0.943$ for wood chip mulch on slopes up to $50 \%$ (Fig. 3a). In addition, the effect of seeding and regrowth of vegetation on soil erosion have been described through $C$ factor. It was set equal to 0.13 , corresponding to the mean value of $C$ on the burned area prior to the fire occurrence (Fig. 3b).

5. The fifth scenario analyzes the effectiveness in capturing soil losses by erosion barriers or trenches on arable land. Barriers at a distance of $50 \mathrm{~m}$ along the contour lines were placed on cropland. This treatment is applied to a share of $35 \%$ of the burned area. Barriers' application as rehabilitation treatments is usually modeled by modifying RUSLE $P$ factor. Wischmeier and Smith (1978) and later Terranova et al. (2009) propose a $P$ factor of 0.2 for reverse bench barriers. Myronidis et al. (2010) distinguished $P$ factor for treatments and slope. They set $P=0.85$ for branch piles and wood boards on gentle slopes $(<30 \%), P=0.75$ for branch piles and wood boards or log barriers on steeper slopes (30 to $50 \%$ ), and $P=1$ for slopes greater than $50 \%$.

In this study, taking into account the slope influence in the capturing effect of the erosion barriers, the $P$ factor values introduced by Myronidis et al. (2010) were used (Fig. 3c).

6. The sixth scenario considers the combination of all rehabilitation practices described in the previous scenarios 3, 4 and 5. In particular, the effectiveness of the treatments' combination is tested by assuming the following pattern: tilling all over the burned area, mulching on woodland and erosion barriers, or trenching on arable land. The $P$ factor has been set accordingly as shown in Fig. $3 \mathrm{~d}$, and the $C$ factor is the same as in scenario 4 (Fig. 2f). 
Table 4. Simulated soil loss corresponding to the six studied scenarios. Erosion in natural conditions (scenario 1) has been reported both for Rio Mannu Basin and for the sub-area subjected to treatments in scenarios 2-6. Soil losses corresponding to basin sub-area under treatments are reported in scenarios 2-6.

\begin{tabular}{lrrr}
\hline $\begin{array}{l}\text { Simulated soil loss } \\
\left(\mathrm{t} \mathrm{ha}^{-1} \mathrm{yr}^{-1}\right)\end{array}$ & Mean & $\begin{array}{r}\text { 99th per- } \\
\text { centile }\end{array}$ & $\begin{array}{r}\text { 90th per- } \\
\text { centile }\end{array}$ \\
\hline Scenario 1 (basin area) & 1.90 & 19.4 & 5.1 \\
Scenario 1 (sub-area) & 2.01 & 18.6 & 5.6 \\
Scenario 2 (sub-area) & 7.18 & 24.2 & 16.4 \\
Scenario 3 (sub-area) & 6.15 & 21.2 & 14.1 \\
Scenario 4 (sub-area) & 1.78 & 18.0 & 5.4 \\
Scenario 5 (sub-area) & 6.71 & 24.1 & 15.9 \\
Scenario 6 (sub-area) & 1.50 & 15.1 & 4.5 \\
\hline
\end{tabular}

\section{Results and discussion}

Table 4 shows the summary of results where simulated soil loss main statistics, corresponding to the six studied scenarios, are reported. In particular, the statistical analysis of erosion in natural conditions (scenario 1) has been reported both for Rio Mannu Basin and for the sub-area subjected to treatments $\left(47 \mathrm{~km}^{2}\right)$. Soil losses corresponding to basin subarea undertreatments have been analyzed for scenarios 2-6. Moreover, scenario 1 results have been used for model validation in natural conditions.

\subsection{Scenario1: pre-fire condition- model validation}

Mean soil loss calculated over the whole basin amounts to $1.9 \mathrm{tha}^{-1} \mathrm{yr}^{-1}$ (Table 5), that lies in the range of measured erosion data in Sardinia, southern Italy and Mediterranean Europe (cfr. Sect. 2.2)

Zonal statistics underline significant differences in soil losses among areas having different soil condition. Mean soil loss ranges from $0.12 \mathrm{tha}^{-1} \mathrm{yr}^{-1}$ on land classified as pasture, to $4.5 / 5.6 \mathrm{tha}^{-1} \mathrm{yr}^{-1}$ on areas cultivated with vines or olive trees, up to $20.5 \mathrm{tha}^{-1} \mathrm{yr}^{-1}$ in areas with little or no vegetation cover. The analysis shows values greater than $30 \mathrm{tha}^{-1} \mathrm{yr}^{-1}$ occurring in very few cells of the basin $(0.24 \%)$. In addition, the 99th percentile of the whole area soil loss is $19.4 \mathrm{tha}^{-1} \mathrm{yr}^{-1}$, and $90 \%$ is $5.05 \mathrm{tha}^{-1} \mathrm{yr}^{-1}$ (Fig. 4).

In detail, peak simulated soil losses in Rio Mannu Basin corresponds to areas with spare vegetation, olive groves or vineyards. For these land use classes, zonal statistics provide peak soil losses of 55.4, 13.72 and $10.9 \mathrm{tha}^{-1} \mathrm{yr}^{-1}$, respectively. Indeed, peak values of $55.4 \mathrm{tha}^{-1} \mathrm{yr}^{-1}$ occur in very few cells $(0.2 \%)$ where the combination of steep slopes, high LS factor and $C$ factor lead to such maxima. Cerdan et al. (2010), during their field experiments in the Mediterranean environment, observed erosion on bare soil of $9.05 \mathrm{tha}^{-1} \mathrm{yr}^{-1}$ and on vineyards of $8.62 \mathrm{tha}^{-1} \mathrm{yr}^{-1}$. Model performances in reproducing soil losses in selected soil uses as pasture, forage crops, and cereals have been assessed by comparison with Ottava field campaigns measurements, the field site in the northern part of the Rio Mannu Basin.

Model simulations have been carried out both for a subarea located in the proximity of Ottava study site and for the whole Rio Mannu Basin by using rainfall input from measured rainfall of the same time period of when the experiment took place. Data coming from Sassari rain gauge, the closest to Ottava, were used for sub-area simulation, while for Rio Mannu properly spatialized data from 7 rain gauges formed the model input. Results, reported in detail in Table 6, show good agreement with measurements, especially among sub area simulations and the second experiment results, reporting mean erosion of 1.08 and $0.86 \mathrm{tha}^{-1} \mathrm{yr}^{-1}$ respectively. The model, despite its simplicity, adequately reproduces observed soil loss for the different land uses.

\subsection{Scenario 2: fire effect on erosion}

Soil losses in the burned areas are considerably higher than pre-fire conditions, the mean soil loss being $7.18 \mathrm{tha}^{-1} \mathrm{yr}^{-1}$, while maximum value is $45.1 \mathrm{tha}^{-1} \mathrm{yr}^{-1}$. The 99 th percentile lies at $24.4 \mathrm{tha}^{-1} \mathrm{yr}^{-1}$, and 90th percentile at $16.4 \mathrm{tha}^{-1} \mathrm{yr}^{-1}$. In the pre-fire scenario, soil loss within the same area reaches a mean rate of only $2.01 \mathrm{tha}^{-1} \mathrm{yr}^{-1}$, and a maximum of $41.5 \mathrm{tha}^{-1} \mathrm{yr}^{-1}$. These values show that fire affects erosion by increasing mean soil loss of almost $260 \%$ (Fig. 5a). Again, only a very small percentage of cells $(0.20 \%)$ have extremely high erosion values, above $30 \mathrm{tha}^{-1} \mathrm{yr}^{-1}$.

Before commenting on this increase, it should be kept in mind that the variability of measured data concerning postfire erosion is unavoidable, depending on several factors, such as, among others, site-specific characteristics, fire severity, rainfall intensity and rainfall.

The few measured data on burned plots in Sardinia are those from Rio S.Lucia (Ollesch and Vacca, 2002; Vacca et al., 2000), from Pattada (Rivoira et al., 1989) and from Ottava (Porqueddu and Roggero, 1994). Field experiments in S.Lucia basin report mean yearly soil loss on burned pasture lands of $0.06 \mathrm{t} \mathrm{ha}^{-1}$, less than soil loss on slopes covered with shrub $\left(0.11 \mathrm{tha}^{-1}\right)$ and with Eucalyptus $\left(0.23 \mathrm{tha}^{-1}\right)$; in Pattada, the erosion on burned slope is $0.014 \mathrm{tha}^{-1} \mathrm{yr}^{-1}$, less than on ploughed land $\left(0.049 \mathrm{tha}^{-1} \mathrm{yr}^{-1}\right)$, grassland $\left(0.048 \mathrm{tha}^{-1} \mathrm{yr}^{-1}\right)$, natural pasture $\left(0.033 \mathrm{tha}^{-1} \mathrm{yr}^{-1}\right)$ and shrub $\left(0.025 \mathrm{tha}^{-1} \mathrm{yr}^{-1}\right)$; in Ottava, soil losses of $0.23 \mathrm{tha}^{-1} \mathrm{yr}^{-1}$ have been observed on burned plot, as shown in Table 1. In all three cases, the erosion values on burned soil do not significantly differ from values on unburned slopes. The authors themselves underline that such low values are probably not representative of the uncontrolled wildfire impact on soil losses and they are probably due to the very low severity of fire. 
Table 5. Simulated soil losses in the area of Ottava.

\begin{tabular}{|c|c|c|c|c|c|}
\hline \multirow{3}{*}{$\begin{array}{l}\text { Study } \\
\text { area }\end{array}$} & \multirow{3}{*}{$\begin{array}{l}\text { Mean yearly } \\
\text { precipitation } \\
(\mathrm{mm})\end{array}$} & \multirow[b]{3}{*}{ Land cover } & \multirow{3}{*}{$\begin{array}{r}\text { Area } \\
\left(\mathrm{km}^{2}\right)\end{array}$} & \multicolumn{2}{|c|}{ Simulated soil losses } \\
\hline & & & & \multicolumn{2}{|c|}{ Loss $\left(\mathrm{tha}^{-1} \mathrm{yr}^{-1}\right)$} \\
\hline & & & & mean & $\max$ \\
\hline \multirow{9}{*}{$\begin{array}{l}\text { Rio Mannu } \\
\text { (Around Ottava) }\end{array}$} & \multirow{9}{*}{$\begin{array}{l}530 \\
\text { (Sassari } \\
\text { rain gauge) }\end{array}$} & Olive groves & 0.5 & 1.5 & 5.86 \\
\hline & & Complex cultivation patterns & 1.24 & 1.03 & 12.41 \\
\hline & & Natural pasture & 0.1 & 0.02 & 0.09 \\
\hline & & Non-irrigated arable land & 1.63 & 1.61 & 14.76 \\
\hline & & Annual crops with permanent crops & 0.02 & 0.3 & 0.48 \\
\hline & & Broad-leaved forests & 0.02 & 0.02 & 0.07 \\
\hline & & Mediterranean maquis/sclerophyllous vegetation & 0.17 & 0.07 & 0.26 \\
\hline & & Natural transitional woodland-shrub & 0.09 & 0.03 & 0.23 \\
\hline & & Other & 1.17 & 0 & 0 \\
\hline \multirow{10}{*}{$\begin{array}{l}\text { Rio Mannu } \\
\text { (whole basin) }\end{array}$} & \multirow{10}{*}{$\begin{array}{l}528 \\
\text { ( } 7 \text { rain } \\
\text { gauges) }\end{array}$} & Permanent crops & 79.30 & 4.17 & 65.20 \\
\hline & & Annual crops & 10.00 & 1.27 & 20.47 \\
\hline & & Forests & 39.60 & 0.12 & 0.88 \\
\hline & & Moors and heathland & 55.50 & 0.14 & 0.83 \\
\hline & & Arable land & 330.30 & 2.15 & 35.19 \\
\hline & & Pastures & 67.80 & 0.15 & 0.91 \\
\hline & & Spare vegetated areas & 1.50 & 20.50 & 69.02 \\
\hline & & Transitional woodland-shrub & 14.10 & 0.14 & 0.77 \\
\hline & & Agro-forestry areas & 9.40 & 1.60 & 9.88 \\
\hline & & Other & 40.50 & 0.00 & 0.00 \\
\hline
\end{tabular}

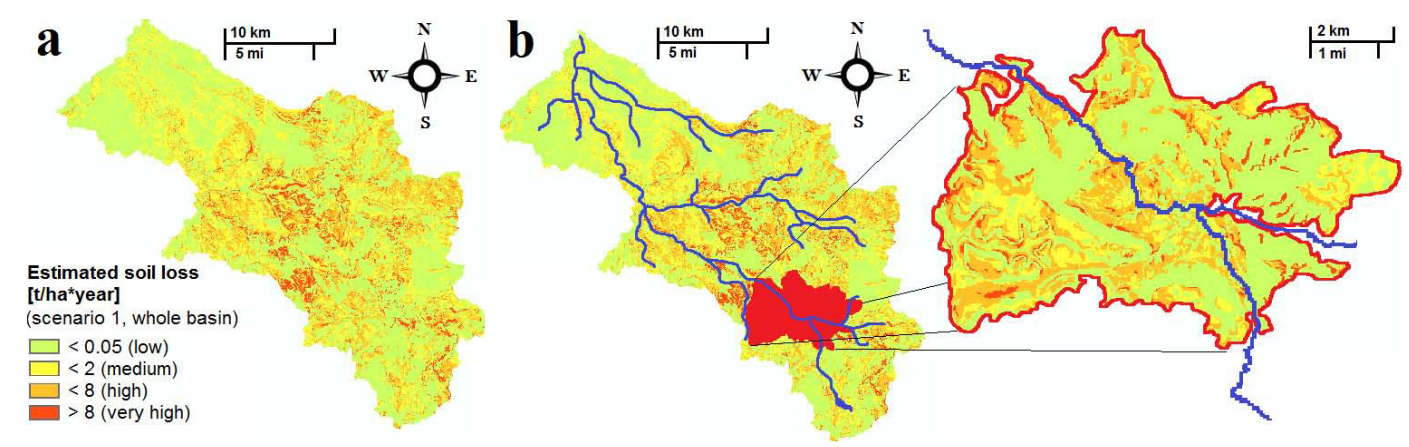

Fig. 4. Simulated soil losses under natural conditions (Scenario 1).

Some more useful evidence of fire forcing on erosion can be inferred from other studies, most of them carried out in a Mediterranean environment, pointing out how most of the fire effect on soil loss depends on fire severity. Soto and DiazFerros (1998) measured, in the first year after fire in Monte Pedroso (Galicia, Spain), soil loss of $12.4 \mathrm{tha}^{-1}$ on highseverity burned plots, and on average $4.9 \mathrm{tha}^{-1}$ on two lowseverity burned plots, whereas the control plot erosion in the same year was $1.96 \mathrm{tha}^{-1}$. These values show an increase in erosion of $150 \%$, passing from unburned to low-severity burned, and of $530 \%$ from unburned to high-severity burned plots. Moreover, measurements after several wildfires in the Colorado Front Range showed soil losses of 0.05, of 2 and of $2-10 \mathrm{tha}^{-1} \mathrm{yr}^{-1}$ respectively in areas burnt by low, medium and high severity fire (Benavides-Solorio and Mac Donald,
2005), representing an increase of more than two orders of magnitude from low severity to high severity fire. Further, mean post-fire erosion estimations in Greece report an increase of $570 \%$ (Vafeidis et al., 2007) in post-fire erosion, and plot scale erosion rates after rainfall simulations in the Branega catchment in Liguria (Italy) show ratios of 143 to 162 between a recently burned plot and a long unburned one, depending on soil moisture conditions before rainfall (Rulli et al., 2006).

Accordingly, simulation results in this study highlight the impact of fire in enhancing soil losses, showing the increase of maximum and mean erosion in the burned areas, as well as the increase of the percentage of basin area affected by large soil losses (high level of erosion) (Table 4). 
Table 6. Simulated soil losses vs. measured soil losses for the area of Ottava and for the Rio Mannu Basin.

\begin{tabular}{|c|c|c|c|c|}
\hline & $\begin{array}{c}\text { Ottava } \\
1989-1991\end{array}$ & $\begin{array}{c}\text { Ottava } \\
1994-1997\end{array}$ & $\begin{array}{l}\text { Rio Mannu } \\
\text { at Ottava }\end{array}$ & $\begin{array}{l}\text { Rio Mannu } \\
\text { whole basin }\end{array}$ \\
\hline $\begin{array}{l}\text { Observed } \\
\text { precipitation } \\
\left(\mathrm{mm} \mathrm{yr}^{-1}\right)\end{array}$ & 569 & 514 & $\begin{array}{c}530 \\
\text { (Sassari } \\
\text { rain gauge) }\end{array}$ & $\begin{array}{c}528 \\
\text { (7 Rain } \\
\text { gauges) }\end{array}$ \\
\hline Soil use & \multicolumn{2}{|c|}{ Measured soil loss ( $\left.\mathrm{tha}^{-1} \mathrm{yr}^{-1}\right)$} & \multicolumn{2}{|c|}{ Simulated soil loss $\left(\mathrm{tha}^{-1} \mathrm{yr}^{-1}\right)$} \\
\hline Pasture & 0.26 & 0.06 & 0.02 & 0.15 \\
\hline $\begin{array}{l}\text { Annual forage crop/ } \\
\text { Annual crops }\end{array}$ & 2.43 & 1.78 & 1.61 & 1.27 \\
\hline $\begin{array}{l}\text { Ploughed/Cereal/ } \\
\text { Arable land }\end{array}$ & 4.96 & 0.75 & 1.61 & 2.15 \\
\hline Average soil losses & 2.55 & 0.86 & 1.08 & 1.19 \\
\hline
\end{tabular}
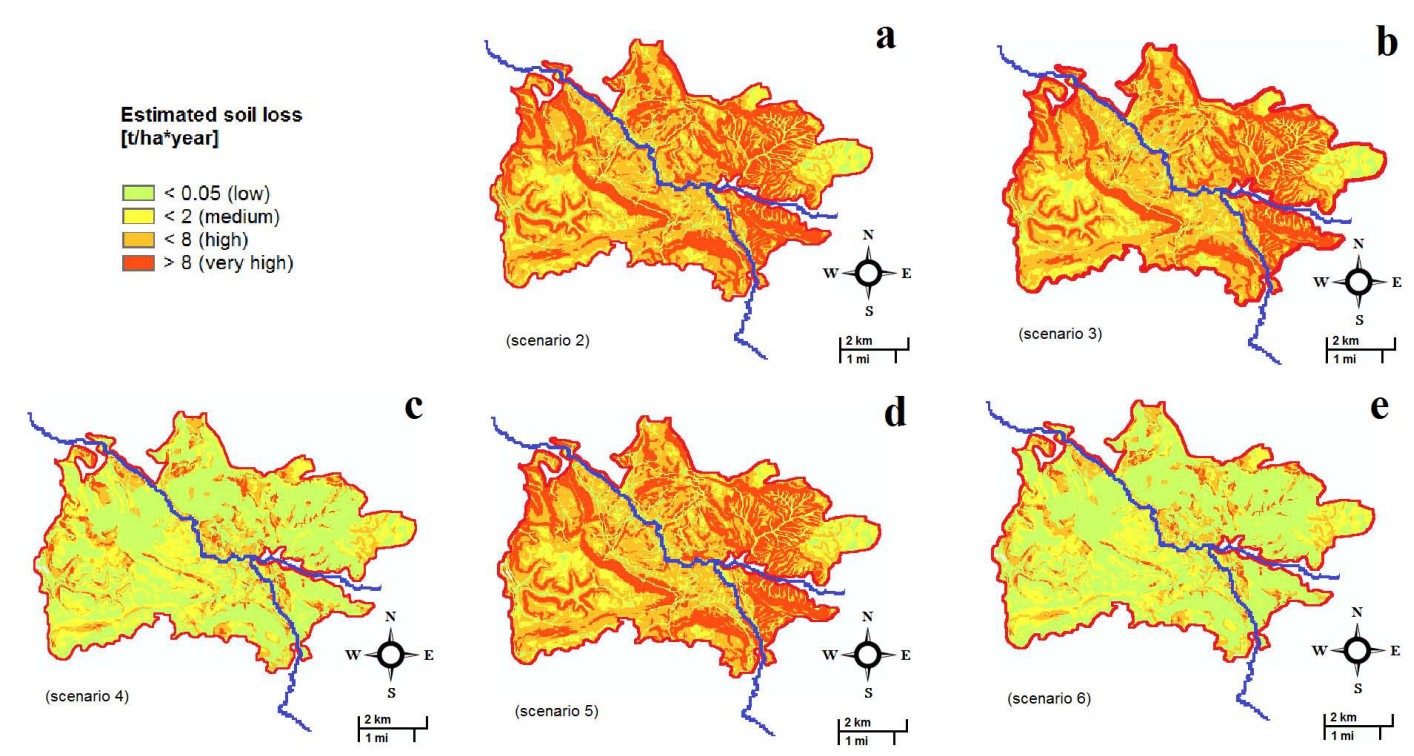

Fig. 5. Simulated soil losses under: (a) burned scenario (Scenario 2); (b) to (d) single soil erosion mitigation treatments (Scenario 3 to 5 ); and (e) combined mitigation treatments (Scenario 6).

\subsection{Scenario 3: soil loss after tilling/ploughing}

Amelioration of the burned soil drainage capacity by ploughing or tilling is modeled to achieve some mitigation of erosion. This treatment does not achieve significant reduction on soil erosion: mean soil loss on burned area is only $14 \%$ less than in the scenario with burned soils (Table 4). After treatment on burned areas, maximum soil loss is around $47 \mathrm{tha}^{-1} \mathrm{yr}^{-1}$, mean value decreases to $6.15 \mathrm{tha}^{-1} \mathrm{yr}^{-1}$, while $99 \%$ of soil loss lies under $21.2 \mathrm{tha}^{-1} \mathrm{yr}^{-1}$, and $90 \%$ under $14.1 \mathrm{tha}^{-1} \mathrm{yr}^{-1}$ (Fig. 5b).

\subsection{Scenario 4: soil loss after mulching on woodland areas}

The mulching treatment reduces soil loss considerably more than the previous treatment: although maximum soil loss calculated is $60.1 \mathrm{tha}^{-1} \mathrm{yr}^{-1}, 99 \%$ of cells show soil loss less than $18.0 \mathrm{tha}^{-1} \mathrm{yr}^{-1}$, and $90 \%$ less than $5.4 \mathrm{tha}^{-1} \mathrm{yr}^{-1}$; mean value is $1.78 \mathrm{tha}^{-1} \mathrm{yr}^{-1}$ (Fig. 5c).

In particular, mulching rehabilitation treatment on woodland (Scenario 4) shows a decreasing of $75 \%$ in mean soil loss calculated over the whole burned area. The decrease in erosion is such that estimated soil loss becomes slightly lower than in the first scenario (Table 4).

Robichaud and Elliot (2006) measured effectiveness for mulching treatments ranging from 63 to $68 \%$ for wood and straw mulch, while for hydromulch it ranged from 19 to 


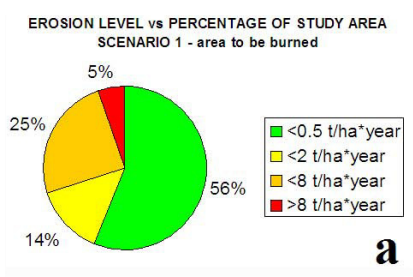

EROSION LEVEL VS PERCENTAGE OF STUDY AREA
SCENARIO 3 $11 \%$

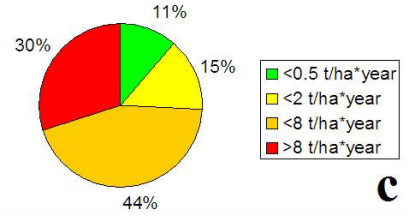

EROSION LEVEL vs PERCENTAGE OF STUDY AREA
SCENARIO 5

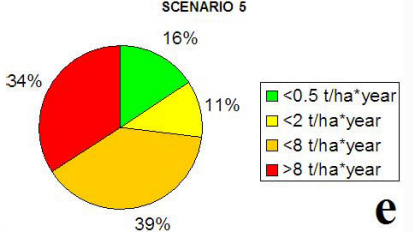

EROSION LEVEL vs PERCENTAGE OF STUDY AREA

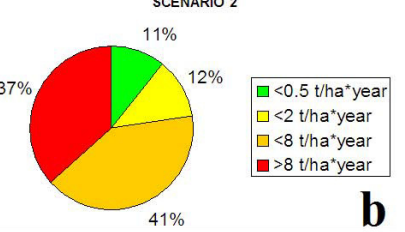

EROSION LEVEL VS PERCENTAGE OF STUDY AREA
SCENARIO 4

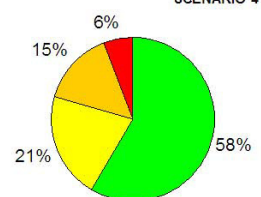

$\square<0.5$ t/ha*year $\square<2$ t/ha*year $\square<8$ t/ha*year n $>8 \mathrm{t} / \mathrm{ha} \mathrm{a}^{*} \mathrm{year}$ EROSION LEVEL VS PERCENTAGE OF STUDY AREA SCENARIO 6

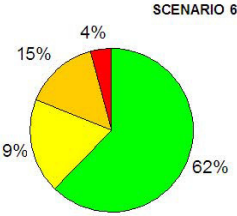

$\square<0.5$ t/ha ${ }^{+}$year $\square<2$ t/ha*year $\square<8$ t/ha*year n $>8 \mathrm{t} /$ ha $a^{*}$ year

Fig. 6. Erosion levels in the study area under the six different scenarios.

$27 \%$. During the first year after a fire in Galicia, Fernàndez et al. (2011) measured that straw mulch application with $80 \%$ soil cover produced a reduction of sediment production of $66 \%$ compared with the control plots, while chip mulch application with $45 \%$ soil cover produced almost no reduction of sediment yield (33 $\mathrm{Mg} \mathrm{ha}^{-1}$ after treatment, $35 \mathrm{Mg} \mathrm{ha}^{-1}$ in the control plot). In our exercise, rehabilitation treatment has been applied on about $45 \%$ of the burned slopes, so that our results agree with the literature-measured data.

\subsection{Scenario 5: soil loss with barriers on cropland}

Scenario 5, consisting on applying barriers on cropland, reduce soil loss less than mulching, but a little bit more than ploughing. In detail, this treatment leads to a decrease of only $6.5 \%$ in mean soil losses on the whole burned area by applying the treatment to a share of $35 \%$. Maximum soil loss on burned areas lies around $45.1 \mathrm{tha}^{-1} \mathrm{yr}^{-1}$, and mean value is $6.71 \mathrm{tha}^{-1} \mathrm{yr}^{-1}, 99 \%$ lies under $24.1 \mathrm{tha}^{-1} \mathrm{yr}^{-1}, 90 \%$ under $15.9 \mathrm{tha}^{-1} \mathrm{yr}^{-1}$. All these values are very close to those obtained in scenario 3 (Fig. 5d).

Robichaud and Elliot (2006) found a reduction in soil losses due to the presence of barriers (contour-felled logs) of about $20-50 \%$ for mid- to high-intensity rainfall events. Accordingly, Fernàndez et al. (2011) observed that the initial mean efficiency of cut-shrub barriers in retaining sediment $(58 \%)$ decreased to $15 \%$ four months after treatment. Measurements in burned plots treated with different barrier types (Robichaud et al., 2007b) showed better performance for contour-felled logs and straw wattle treatment while contour trench showed no significant erosion mitigation effect.

Table 7. Percentage of undertreatment area $\left(47 \mathrm{~km}^{2}\right)$ having different erosion levels.

\begin{tabular}{lrrrr}
\hline \multicolumn{4}{c}{ Erosion Level } \\
\hline Scenario & low & moderate & high & very high \\
\hline Scenario 1 & $63 \%$ & $10 \%$ & $17 \%$ & $10 \%$ \\
Scenario 2 & $11 \%$ & $12 \%$ & $41 \%$ & $36 \%$ \\
Scenario 3 & $11 \%$ & $15 \%$ & $44 \%$ & $30 \%$ \\
Scenario 4 & $58 \%$ & $21 \%$ & $15 \%$ & $6 \%$ \\
Scenario 5 & $13 \%$ & $12 \%$ & $41 \%$ & $34 \%$ \\
Scenario 6 & $62 \%$ & $19 \%$ & $15 \%$ & $4 \%$ \\
\hline
\end{tabular}

\subsection{Scenario 6: soil loss with application of all rehabilitation treatments on burned areas}

Scenario 6, studying the effects of the combination of the three different rehabilitation treatments, shows mean soil loss lower than the post-fire scenario $(79 \%)$ and also the natural scenario (20\%) (Table 4). Mean soil loss estimated over the Rio Mannu Basin is $1.50 \mathrm{tha}^{-1} \mathrm{yr}^{-1}$, maximum soil loss is $52.7 \mathrm{tha}^{-1} \mathrm{yr}^{-1} ; 99 \%$ of cells have soil loss less than $15.1 \mathrm{tha}^{1-} \mathrm{yr}^{-1}, 90 \%$ less than $4.5 \mathrm{tha}^{-1} \mathrm{yr}^{-1}$ (Fig. 5e).

\subsection{Analysis of the erosion levels distribution on the study area}

Besides mean and maximum estimated soil losses, an interesting feature to observe for the six scenarios is the erosion levels distribution on the study area. In the present study four erosion levels have been defined: low, moderate, high, very high, having soil loss less than $0.5 \mathrm{tha}^{-1} \mathrm{yr}^{-1}$; comprised between 0.5 and $2 \mathrm{tha}^{-1} \mathrm{yr}^{-1}$; comprised between 2 and $8 \mathrm{tha}^{-1} \mathrm{yr}^{-1}$; greater than $8 \mathrm{tha}^{-1} \mathrm{yr}^{-1}$, respectively.

In the first scenario, the area of the Rio Mannu Basin classified at very high erosion level is $5 \%$ of total area, while $53 \%$ of the basin presents low erosion level. High and moderate erosion levels cover 20 and $22 \%$ of the area, respectively.

Regarding the sub-area, $63 \%$ shows low erosion level, $10.3 \%$ moderate, $16.6 \%$ high and $10.1 \%$ very high (Fig. 6a).

In scenario 2 , the area having very high level raises to $36 \%$, while low erosion level decreases to $11 \%$ of the area. Also high level shows a considerable increase to $41 \%$ of the total burned area, while moderate class remains around $12 \%$ (Fig. 6b).

In the third scenario, even where no significant reduction in terms of mean or maximum soil loss estimations have been observed compared with scenario 2 , there is nevertheless a remarkable decrease in the percentage of area affected by very high soil loss, which is $30 \%$, while high, moderate, and low are respectively 44, 15 and $11 \%$ (Fig. 6c).

Scenario 4, already reporting a significant contribution for soil loss mitigation in terms of mean or maximum soil loss 
at treated-area scale, shows that the effect of treatment in reducing soil loss is made more evident by the distribution of erosion levels over the area: only $6 \%$ of the area represents very high erosion level, $15 \%$ high, $21 \%$ moderate and as much as $58 \%$ low (Fig. 6d).

In the fifth scenario, very high erosion affects $34 \%$ of the area, and $13 \%$ of it is classified as low in erosion level. This means an increase in low erosion zones and a decrease in very high erosion zones, while high or moderate erosion affects the same percentage of area as in the second scenario. As noticed before, the erosion barriers' performance would be more appreciable if studied with a model for sediment propagation (Fig. 6e).

The last scenario shows that the area representing low erosion is $62 \%$, whereas very high erosion occurs on just $4 \%$ of it (Fig. 6f). A summary of the erosion levels corresponding to the analyzed treatments is reported in Table 7.

\section{Conclusions}

In this paper a simple distributed model based on the RUSLE equation has been presented and the analysis of several posterosion mitigation strategies has been carried out for the Rio Mannu Basin. Modeling watershed response to erosion rehabilitation treatments can be useful in choosing the better soil loss mitigation methods, particularly in Mediterranean areas experiencing a large number of wildfires every year, most of them at the interface with urban areas.

Model results compared with the available field measurements and the detailed analysis of the treatments scenarios show distributed RUSLE capacity to be a simple and useful model for correctly reproducing soil losses in Rio Mannu Basin and also for selecting the most appropriate treatment related to site characteristics. Nevertheless, a distributed model capable of representing sediment dynamics could better assess the efficiency of mitigation strategies, especially for erosion barriers. Moreover, the lack of both 2009 post-fire event detailed observations and also erosion mitigation strategies implementation on the study area highlight that the application pattern of the soil loss reduction techniques presented in this paper need be validated through field campaigns.

Results showing changes both in soil losses total and on erosion levels among the six scenarios demonstrate the effectiveness of mitigation treatments on the Rio Mannu Basin burned area, as well as the importance of choosing the most appropriate erosion mitigation strategies related to site characteristics. Choosing how to restore channels and slopes after a wildfire is an important issue, which could be properly dealt with if more effort were spent collecting field data before and after fires. In fact, most of the existing models, such as the RUSLE-based model used in this study, try to describe and quantify post-fire erosion considering variables like fire severity, percentage of bare soil, rainfall erosivity, and soil repellency, despite the fact that measures like these are not always available. Fire severity corrected evaluation is the key factor, because it prioritizes the mitigation treatment intervention areas. In Italy, this issue is of particular concern because, according with the Article 2 of Regulation (EEC) No 2158/92, which states that each Member State provide a list of areas classified by degree of risk, the Mediterranean regions of Italy are classified as high-risk areas (i.e. areas in which the risk of forest fire presents a serious threat to the ecological balance and the safety of people or goods) (JRC, 2008).

In the USA, Burned Area Emergency Rehabilitation (BAER) activities have been established for assessing the need and implementation of post-fire treatments and provide a choice of treatments and essential protection (Neary, 2005; Robichaud and Elliot, 2006). Since any treatment recommendation has to be matched to the specific environmental and climatic conditions of the area, models and parameterizations based on measurements made in the USA do not necessarily apply to Sardinian conditions. The choice of which treatment to apply, if any, should be based on careful scenario analysis and this can be done only if watershed characteristics and response to rehabilitation practices are well assessed through modeling based on field data parameterization. Further efforts should therefore be directed to collect field data for the Mediterranean environment.

Accurate estimation of potential soil losses, coupled with the evaluation of watershed rehabilitation effectiveness, can be useful in maintaining soil loss and soil renewal rate at equilibrium, which is a critical issue for successful land management. Mitigation strategies of forest fire effects in the Mediterranean areas should be aimed toward sustainable coexistence with forest fires, in terms of both human security and ecological processes.

Acknowledgements. The financial support provided for this work by Regione Sardegna through the project named "Methodology and indicators for fire risk assessment in rural-urban interface of Mediterranean environment" (MIUR CRP 2 565) is gratefully acknowledged.

Edited by: M. Mikos

\section{References}

Acutis, M., Argenti, G., Bersani, L., Bullitta, P., Caredda, S., Cavallero, A., Giordani, C., Grignani, C., Pardini, A., Porqueddu, C., Reyneri, A., Roggero, P. P., Sulas, L., Talamucci, P., and Zanchi, C.: Effetti di tipologie di suolo e colture foraggere sulle perdite per ruscellamento di azoto, fosforo e potassio in differenti areali italiani, Rivista di agronomia, 30, 329-338, 1996.

Andreu, V., Imeson, A. C., and Rubio, J. L.: Temporal changes in soil aggregates and water erosion after a wildfire in a Mediterranean pine forest, Catena, 44, 69-84, 2001. 
Badia, D. and Marti, C.: Seeding and mulching treatments as conservation measures of two burned soils in the central Ebro valley, NE Spain, Arid Soil Res. Rehab., 13, 219-232, 2000.

Bautista, S., Robichaud, P. R., and Bladé, C.: Post-fire mulching, in: Fire Effects on Soils and Restoration Strategies, edited by: Cerdà A. and Robichaud P. R., Science Publishers, Enfield, NH, 353-372, 2009.

Benavides-Solorio, J. D. and Mac Donald, L. H.: Measurement and prediction of postfire erosion at the hillslope scale, Colorado Front Range, Int. J. Wildland Fire, 14, 1-18, 2005.

Bocchiola, D., Rulli, M. C., and Rosso, R.: A flume experiment on the formation of wood jams in rivers, Water Resour. Res., 44, W02408, doi:10.1029/2006WR005846, 2008.

Cebecauer, T., Súri, M., Hofierka, J., and Fulajtár, E.: Corine Land Cover in the context of soil erosion assessment at a regional scale, Workshop CORINE Land Cover 2000 in Germany and Europe and its use for environmental applications, 20-21 January 2004, Berlin, UBA Texte 04/04, ISSN 0722-186X, 131137, 2004.

Cerdà, A.: Changes in overland flow and infiltration after a rangeland fire in Mediterranean scrubland, Hydrol. Process., 12, 10311042, 1998.

Cerda, A. and Doerr, S. H.: Influence of vegetation recovery on soil hydrology and erodibility following fire: an eleven-year investigation, Int. J. Wildland Fire, 14, 423-437, 2005.

Cerda, A. and Doerr, S. H.: The effect of ash and needle cover on surface runoff and erosion in the immediate post-fire period, Catena, 74, 256-263. doi:10.1016/S0341-8162(02)000279, 2008.

Cerdan, O., Govers, G., Le Bissonnais, Y., Van Oost, K., Poesen, J., Saby, N., Gobin, A., Vacca, A., Quinton, J., Auerswald, K., Klik, A., Kwaad, F. J. P. M., Raclot, D., Ionita, I., Rejman, J., Rousseva, S., Muxart, T., Roxo, M. J., and Dostal, T.: Rates and spatial variations of soil erosion in Europe: A study based on erosion plot data, Geomorphology, 122, 167-177, 2010.

DeBano, L. F.: The role of fire and soil heating on water repellency in wildland environments: a review, J. Hydrol., 231, 195-206, 2000.

Doerr, S. H., Shakesby, R. A., and Mac Donald, L. H.: Soil Water Repellency: A Key Factor in Post- Fire Erosion, in: Fire Effects on Soils and Restoration Strategies, edited by: Cerdà, A. and Robichaud, P. R., Science Publishers, Enfield, NH, 197-223, 2009.

Elliot, W. J., Hall, D. E., and Graves, S. R.: Disturbed WEPP: Forest Service interfaces for the Water Erosion Prediction Project (WEPP) computer model, Moscow, ID: US Department of Agriculture, Forest Service, Rocky Mountain Research Station, available at: http://forest.moscowfsl.wsu.edu/fswepp (last access: August 2012), 2001.

Emmerich, W. E. and Cox, J. R.: Changes of surface runoff and sediment production after a repeated rangeland burns', Soil Sci. Soc. Am. J., 58/1, 199-203, 1994.

Environment protection Agency (APAT): Rainfall database for Sardinia region, Environment protection Agency, Rome, 2009.

European Commission Joint Research Centre Institute for Environment and Sustainability: Assesment of forest fire risk in the European mediterranea region: Comparison of satellite-derived and meteorological indices, RC 49371 EUR 23706 EN ISSN 10185593, Luxembourg, 2008.
European Economic Community: Council Regulation (EEC), No 2158/92 of 23 July 1992 on protection of the Community's forests against fire, Official Journal of the European Union L 217, 1992.

Ferreira, A. J. D., Sande Silva, J., Coelho, C., Boulet, A. K., and Keizer, J. J.: The Portuguese Experience in Managing Fire Effects, in: Fire Effects on Soils and Restoration Strategies, edited by: Cerdà A. and Robichaud, P. R., Science Publishers, Enfield, NH, 353-372, 2009.

Fernández, C., Vega, J. A., and Vieira, D. C. S.: Assessing soil erosion after fire and rehabilitation treatments in NW Spain: Performance of RUSLE and revised Morgan- Morgan-Finney models, Land Degrad. Dev., 21, 58-67, doi:10.1002/ldr.965, 2010.

Fernández, C., Vega, J. A., Jiménez, E., and Fonturbel, M. T.: Effectiveness of three post-fire treatments at reducing soil erosion in Galicia (NW Spain), Int. J. Wildland Fire, 20, 104-114, 2011.

Flanagan, D. C. and Nearing, M. A.: USDA-Water Erosion Prediction Project: Hillslope profile and watershed model documentation, NSERL Report No. 10, West Lafayette, USDA-ARS National Soil Erosion Research Laboratory, 1995.

Fox, D. M., Maselli, F., and Carrega, P: Using SPOT images and field sampling to map burn severity and vegetation factors affecting post forest fire erosion risk, Catena, 75/3, 326-335, 2008.

Fulé, P. Z., Ribas, M., Gutiérrez, E., Vallejo, R., and Kaye, M. W.: Forest structure and fire history in an old Pinus nigra forest, eastern Spain, Forest Ecol. Manag., 255, 1234-1242, 2008.

Grimaldi, S., Teles, V., and Bras, R. L.: Sensitivity of a physicallybased method of terrain interpolation to variance of input data and to the constraint of an enforced surface drainage direction, Earth Surf. Process. Landf., 29, 587-597, 2004.

Grimaldi, S., Nardi, F., Benedetto, F. D., Istanbulluoglu, E., and Bras, R. L.: A physically-based method for removing pits in digital elevation models, Adv. Water Resour., 30/10, 2151-2158, doi:10.1016/j.advwatres.2006.11.016, 2007.

Istituto Geografico Militare. Pedological map of Sardinia, 1962.

Keizer, J. J., Doerr, S. H., Malvar, M. C., Prats, S. A., Ferreira, R. S. V., Oñate, M. G., Coelho, C. O. A., and Ferreira, A. J. D.: Temporal variation in topsoil water repellency in two recently burnt eucalypt stands in north-central Portugal, Catena, 74/3, 192-204, 2008.

Larsen, I. J. and Mac Donald, L. H.: Predicting postfire sediment yields at the hillslope scale: Testing RUSLE and Disturbed WEPP, Water Resour. Res., 43, W11412, doi:10.1029/2006WR005560, 2007.

McCool, D. K., Foster, G. R., Renard, K. G., Yoder, D. C., and Weesies, G. A.: The Revised Universal Soil Loss Equation, Department of Defense/Interagency Workshop on Technologies to Address Soil Erosion on Department of Defense Lands, San Antonio, TX, 11-15 June, 1995.

Menduni, G., Pagani, A., Rulli, M. C., and Rosso R.: A nonconventional watershed partitioning method for semi-distributed hydrological modelling: the package ALADHYN, Hydrol. Process., 16, 277-291, 2002.

Moody, J. A., Martin, D. A., Haire, S. L., and Kinner, D. A.: Linking runoff response to burn severity after a wildfire, Hydrol. Process., 22, 2063-2074, doi:10.1002/hyp.6806, 2008.

Moody, J. A., Shakesby R. A., Robichaud, P. R., Cannon, S. H., and Martin, D. A.: Current research issues related to postwildfire runoff and erosion processes, Earth-Sci. Rev. 122, 
10-37, doi:10.1016/j.earscirev.2013.03.004, 2013.

Moore, I. D. and Burch, G. J.: Physical basis of the length-slope factor in the Universal Soil Loss Equation, in: Soil Sci. Soc. Am. J., 50, 1294-1298, 1986.

Myronidis, D. I., Emmanouloudis, D. A., Mitsopoulos, I. A., and Riggos, E. E.: Soil Erosion Potential after Fire and Rehabilitation Treatments in Greece, in: Environ. Model Assess., 15, 239-250, doi:10.1007/s10666-009-9199-1, 2010.

Neary, D. G., Ryan, K. C., and DeBano, L. F. (Eds.): Wildland fire in ecosystems: effects of fire on soils and water. Gen. Tech. Rep. RMRS-GTR-42-.4. Ogden, UT: US Department of Agriculture, Forest Service, Rocky Mountain Research Station, 2005 (revised 2008).

Ollesch, G. and Vacca, A.: Influence of time on measurement results of erosion plot studies, Soil. Till Res., 67, 23-39, 2002.

Pausas, J. G. and Paula, S.: Fuel shapes the fire-climate relationship: evidence from Mediterranean ecosystems, Global Ecol. Biogeogr., 21, 1074-1082, doi:10.1111/j.1466-8238.2012.00769.x, 2012.

Pausas, J. G. and Verdú, M.: Fire reduces morphospace occupation in plant communities, Ecology, 89, 2181-186, 2008.

Petroselli, A.: LIDAR data and hydrological applications at the basin scale, GIScience and remote sensing, GIScie. Remote Sens., 49/1, 139-162, doi:10.2747/1548-1603.49.1.139, 2012.

Petroselli A. and Alvarez A.: The flat area issue in DEMs and its consequences on the rainfall-runoff modeling, GISci. Remote Sens., 49, 711-734, doi:10.2747/1548-1603.49.5.711, 2012

Porqueddu, C. and Roggero, P. P.: Effect of the agronomic techniques for the improvement of forage production on soil erosion of slopes in a Mediterranean environment, Rivista di agronomia, 28/4, 364-370, 1994 (in Italian).

Porqueddu, C., Caredda, S., Sulas, L., Farina, R., and Fara, G.: Impact of crop intensification on soil erosion in farming systems based on cereal - annual and permanent forage production in a Sardinian hilly region, Rivista di agronomia, 35/1, 45-50, 2001 (in Italian).

Ranzi, R., Than Hung, L., and Rulli, M. C.: A RUSLE approach to model suspended sediment load in the Lo river (Vietnam): Effects of reservoirs and land use changes, J. Hydrol., 422, 17-29, 2012.

Regione Autonoma della Sardegna: Water Resources Report, 2006. Regione Autonoma della Sardegna: Fire service statistics, 2009a.

Regione Autonoma della Sardegna: Hydrological Annals, Istituto Idrografico di Cagliari, 2009b.

Renard, K. G., Foster, G. R, Weesies, G. A., McCool, D. K., and Yoder, D. C.: Predicting soil erosion by water: A guide to conservation planning with the Revised Universal Soil Loss Equation (RUSLE), Agric Handb, 703, US Department of Agriculture, Washington D.C., USA, 1997.

Rivoira, G., Roggero, P. P., and Bullitta, S. M.: Improvement techniques and erosion of hillside pasturelands, Rivista di agronomia, 23/4, 372-377, 1989 (in Italian).

Robichaud, P. R. and Elliot, W. J.: Protection from erosion following wildfire, Presentation at the 2006 ASABE Annual International Meeting, ASABE Paper No. 068009, American Society of Agricultural and Biological Engineers, 2006.

Robichaud, P. R., Beyers, J. L., and Neary, D. G.: Evaluating the effectiveness of postfire rehabilitation treatments, Gen. Tech. Rep., RMRS-GTR-63, USDA Forest Service, 2000.
Robichaud, P. R., Elliot, W. J., Pierson, F. B., Hall, D. E., Moffet, C. A., and Ashmun, L. E.: Erosion Risk Management Tool (ERMiT) user manual (version 2006-01.18), Gen. Tech. Rep., RMRS-GTR188, USDA Forest Service, 2007a.

Robichaud, P. R., Pierson, F. B., Brown R. E., and Wagenbrenner, J. W.: Measuring effectiveness of three postfire hillslope erosion barrier treatments, western Montana, USA, Hydrol. Process., 22, 159-170, 2007b.

Robichaud, P. R, Ashmun, L. E., and Sims, B. D.: Post-Fire Treatment Effectiveness for Hillslope Stabilization, Gen. Tech. Rep., RMRSGTR-240, USDA Forest Service, Rocky Mountain Research Station, 2010.

Rosso, R., Rulli, M. C., and Bocchiola, D.: Transient catchment hydrology after wildfires in a Mediterranean basin: runoff, sediment and woody debris, Hydrol. Earth Syst. Sci., 11, 125-140, doi:10.5194/hess-11-125-2007, 2007.

Rulli, M. C. and Rosso, R.: Modeling catchment erosion after wildfires in the San Gabriel Mountains of southern California, Geophys. Res. Lett., 32/19, 1-4, doi:10.1029/2005GL023635, 2005.

Rulli, M. C. and Rosso, R.: Hydrologic response of upland catchments to wildfires, Adv. Water Resour., 30, 2072-2086, 2007.

Rulli, M. C., Spada, M., Bozzi, S., Bocchiola, D., and Rosso, R.: Rainfall simulations on a fire disturbed Mediterranean area, J. Hydrol., 327/3-4, 323-338, 2006.

Shakesby, R. A.: Post-wildfire soil erosion in the Mediterranean: Review and future research directions, Earth Sci. Rev., 105, 71100, 2011.

Soto, B. and Diaz-Fierros, F.: Runoff and soil erosion from areas of burnt scrub: comparison of experimental results with those predicted by the WEPP model, Catena, 31, 257-270, 1998.

Soulis, K., Valiantzas, J., and Dercas, N.: Modelling forest fires hydrological impact using spatio-temporal geographical data, International Congress on Environmental Modelling and Software, Modelling for Environment's Sake, Fifth Biennial Meeting (iEMSs), Ottawa, Canada, 2010.

Terranova, O., Antronico, L., Coscarelli, R., and Iaquinta, P.: Soil erosion risk scenarios in the Mediterranean environment using RUSLE and GIS: An application model for Calabria (southern Italy), Geomorphology, 112, 228-245, 2009.

Ursino, N. and Rulli, M. C.: Hydrological minimal model for fire regime assessment in a Mediterranean ecosystem, Water Resour. Res., 47/11, W11526, doi:10.1029/2011WR010758, 2011.

Vacca, A., Loddo, S., Ollesch, G., Puddu, R., Serra, G., Tomasi, D., and Aru, A.: Measurement of runoff and soil erosion in three areas under different land use in Sardinia, Italy, Catena, 40, 6992, 2000.

Vafeidis, A. T., Drake, N. A., and Wainwright, J.: A proposed method for modelling the hydrologic response of catchments to burning with the use of remote sensing and GIS, Catena, 70, 396409, 2007.

Van Rompaey, A. J. J., Bazzoffi, P., Jones, R. J. A., Montanarella, L., and Govers, G.: Validation of Soil Erosion Risk Assessments in Italy, European Soil Bureau Research Report No.12, EUR 20676 EN, Office for Official Publications of the European Communities, Luxembourg, 2003.

Van Rompaey, A. J. J., Bazzoffi, P., Jones, R. J. A., and Montanarella, L.: Modeling sediment yields in Italian catchments, Geomorphology, 65, 157-169, 2005. 
Wagenbrenner, J. W., Mac Donald, L. H., and Rough, D.: Effectiveness of three post-fire rehabilitation treatments in the Colorado Front Range, Hydrol. Process., 20, 2989-3006, doi:10.1002/HYP.6146, 2006.

Wohlgemuth, P. M., Beyers, J. L., and Hubbert, K. R.: Rehabilitation strategies after fire: The California, USA experience, Fire effects on soils and restoration strategies, edited by: Cerdà A. and Robichaud P. R., Science Publishers, Enfield, NH, 511-535, 2009.
Wischmeier, W. H. and Smith, D. D.: Predicting rainfall erosion losses, Agriculture Handbook, 537, Agriculture Research Service, US Department of Agriculture, Washington, DC, USA, 1978 . 